\title{
The Arab Spring 2010: Puncak Gunung Es Krisis Politik di Kawasan Timur Tengah
}

\section{Sidik Jatmika}

Jurusan IImu Hubungan Internasional, Fakultas IImu Sosial dan IImu Politik, Universitas Muhammadiyah Yogyakarta

Ringroad Barat Tamantirto, Kasihan, Bantul 55183

Email: sidikjatmika@umy.ac.id

\begin{abstract}
Since 2010, number of political uprisings took place in the Arab countries which so called The Arab Spring (at-Thawrât al-'Arabiyyah). The fall of regimes such as in Tunis, Egypt, and Libya, following the massive resistance of people was actually reflect the crisis of legitimacy and the weakness of authority of many political leaders in the region. Moreover, the loyalty of many people in the Arab countries to their leaders was also problematic decision when it has to deal with their primordial affiliations such as ashabiyah, wathanniyah, qaummiyah and ummah. The Arab Spring is a very important political movement which taught us lessons that both leadership and national character building are unfinished and will never be end as a process. This phenomenon also emphasized the importance of political system to be adaptive to the dynamic of domestic political situation and international atmosphere as well. The failure to adapt towards such conditions will causes to the fall of the ruling power. Keywords: crisis of legitimacy, national building, adaptive political system
\end{abstract}

\begin{abstract}
Abstrak
Sejak 2010, sejumlah pemberontakan politik terjadi di Negara-negara Arab yang disebut Arab Spring (at-Thawrât al-'Arabiyyah). Jatuhnya rezim seperti di Tunisia, Mesir, dan Libya, disusul oleh pemberontakan mencerminkan krisis legitimasi dan lemahnya otoritas para pemimpin politik di wilayah tersebut. Selain itu, kesetiaan banyak orang di Negara Arab terhadap pemimpinnya menjadi situasi yang sulit ketika harus berhadapan dengan afiliasi seperti ashabiyah, wathanniyah, qaummiyah and ummah. Arab Spring merupakan gerakan politik sangat penting yang mengajarkan kita kepemimpinan dan karakter pembangunan nasional yang belum selesai dan proses yang tidak akan pernah berakhir. Fenomena ini juga menekankan pentingnya sistem politik untuk adaptif pada dinamika situasi politik domestik dan situasi internasional. Kesalahan untuk beradaptasi pada kondisi tertentu akan menyebabkan jatuhnya kekuasaan.

Kata kunci: krisis legitimasi, pembangunan nasional, sistem politik adaptif
\end{abstract}

\section{PENDAHULUAN}

Muammar Khaddafi, Pemimpin Besar Revolusi Rakyat yang telah memimpin Libya selama 42 tahun (1969-2011) akhirnya tewas dengan cara tragis setelah ditembak kepala dan kedua kakinya. Saat ditemukan hidup-hidup oleh pasukan pemberontak yang tergabung dalam Dewan Transisi Nasional (NTC) ia tengah bersembunyi di sebuah lubang di bawah tanah dan sempat memohon, "Jangan tembak! Jangan tembak!” Penembakan terhadap Khaddafi terjadi tidak lama setelah kejatuhan Sirte ke tangan tentara revolusioner (Ramadhanny, 2011). Nasib Khaddafi kian tragis, karena jenazahnyapun tidak diperlakukan dengan cara layak. Dalam kondisi yang hampir membusuk setelah hampir sepekan dipamerkan di sebuah pasar di Sirte, akhirnya jenazah mantan pemimpin Libya Muammar Khaddafy dimakamkan 
dalam sebuah upacara sederhana di padang gurun yang dirahasiakan.

Tragedi Khaddafi telah memperpanjang deretan kisah tragis yang menimpa beberapa pemimpin Arab pada dekade kedua abad ke-21 ini. Sebelumnya, nasib serupa menimpa Presiden Tunisia Zine Al-Abidine Ben Ali. Pemimpin yang telah berkuasa 23 tahun itu, akibat Revolusi Yasmin, akhirnya melarikan diri ke luar negeri pada tanggal 14 Januari 2010. Hal serupa juga terjadi pada Presiden Mesir Husni Mubarak. Setelah kewalahan menghadapi demonstrasi rakyat selama 18 hari, Presiden Mubarak akhirnya mundur pada tanggal 11 Februari 2011 dan kemudian diadili. ${ }^{1}$

Mengapa berbagai tragedi maupun krisis kepemimpinan yang terjadi pada beberapa pemimpin Arab tersebut penting untuk dikaji para pengamat politik di Indonesia? "Jauh di mata dekat di hati" adalah istilah yang tepat untuk menggambarkan hubungan yang memiliki karakter khas dari waktu ke waktu antara Indonesia dengan bangsa Arab. Artinya, apapun yang terjadi pada bangsa Arab seolah begitu mudah menyentuh syaraf kesadaran bangsa Indonesia. Baik sekedar dukungan, kecaman bahkan juga pengiriman relawan. Bahkan banyak di antara anak bangsa Indonesia yang mengidolakan gaya para pemimpin Arab. Karena itulah, maka bahasan ini memiliki daya tarik tersendiri.

Apakah guncangan terhadap kepemimpinan Khaddafi, Zine Al-Abidine Ben Ali dan Husni Mubarak pada tahun 2010 terjadi secara tiba-tiba ataukah sesungguhnya merupakan hasil akumulasi dari berbagai proses politik sebelumnya? Untuk menjawabnya, tulisan ini akan menelusuri sejarah dinamika proses gelombang demokratisasi dunia dan dampaknya terhadap kawasan Timur Tengah dari waktu ke waktu. Setelah itu akan dikupas fenomena Arab Springs yang terjadi sejak tahun 2010.

\section{PEMBAHASAN}

\section{DINAMIKA GELOMBANG DEMOKRATISASI DUNIA DI} KAWASAN ARAB

Samuel P. Huntington, seorang ilmuwan politik Amerika, menulis tesis mengenai tahapan atau gelombang demokratisasi. Gelombang demokratisasi adalah sekelompok transisi dari rezim-rezin nondemokratis ke rezim-rezim demokratis yang terjadi dalam kurun waktu tertentu dan jumlahnya secara signifikan lebih banyak daripada transisi menuju arah sebaliknya. Sebagian gelombang juga biasanya mencakup liberalisasi atau demokratisasi, sebagian pada sistem-sistem politik yang tidak sepenuhnya menjadi demokratis (Huntington, 1993; Markoff, 2002).

Gelombang Demokratisasi Pertama terjadi di Barat pada paruh pertama abad ke-17. Dimulai dengan revolusi di Inggris pada 14 Januari 1638 yang melahirkan The Fundamental Orders of Connecticut, yang disetujui warga kota Hartford dan kota-kota lainnya yang berdekatan. Gelombang Demokrasi Pertama (1828-1926), oleh Huntington, dirujuk dan dikaitkan dengan Revolusi Prancis dan Revolusi Amerika. Kemunculan lembaga demokrasi nasional sesungguhnya merupakan fenomena abad ke-19 dimana terjadi perkembangan lembaga demokrasi di berbagai negara.

Gelombang Demokrasi Pertama yang panjang ini pada awal abad ke-20 sempat berbalik arah. Hal itu terutama ditandai dengan bangkitnya rezim yang berideologi komunis, fasis dan militeristis ditambah dengan terjadinya perang yang berkedok menyelamatkan demokrasi dunia ternyata malah sebaliknya justru membangkitkan gerakan-gerakan ekstrem kanan maupun kiri yang ingin menghancurkannya. Oleh Huntington, gelombang balik ini terjadi tahun 1922-1942. Di kawasan Timur Tengah, pasca Perang Dunia I (1914-1918), ditandai dengan runtuhnya Khilafah Islamiyah yang berpusat di Istambul dan lahirnya beberapa pemerintahan maupun negara-nasional (nation-state) yang baru. Misalnya Republik Turki, Kerajaan Hejaz, Kerajaan Nejd, dll (Ochsenwald EF Fisher, 1979).

Gelombang demokrasi kedua, dicatat Huntington, berlangsung pasca Perang Dunia II, di mana Indonesia juga muncul sebagai negara baru yang lepas dari kolonialisasi. Pendudukan sekutu atas beberapa negara melahirkan lembaga-lembaga demokrasi di Jerman Barat, Italia, Austria, Jepang dan Korea. Turki dan 
Yunani pada 1940 dan 1950 telah bergerak kearah demokrasi. Begitu pula di Amerika Latin, Uruguay, Brasil dan Kostarika (1940) bergeser ke sistem demokrasi. Pemilu di negara-negara Argentina, Kolombia, Peru, dan Venezuela (1945-1946) melahirkan pemerintahan pilihan rakyat, meskipun Argentina dan Peru bergerak kembali ke arah demokrasi terbatas yang tidak stabil, karena adanya konflik antara pihak militer dengan gerakan Aprista dan Peronista yang sangat populer pada akhir dasa warsa 1950. Di kawasan Timur Tengah lahir beberapa pemerintahan baru maupun negara-nasional baru. Misalnya, terbentuknya Republik Syria dan Libanon(1941) serta pemerintahan Republik Arab Mesir (1947) dan lain-lain.

Gelombang demokrasi kedua yang pendek segera diikuti oleh gelombang balik sekitar tahun 1958-1975. Gelombang balik kedua dimulai dengan apa yang terjadi di Peru pada tahun 1962 ketika pihak militer ikut campur tangan untuk merubah hasil pemilu yang menghasilkan pemimpin dari luar militer yang juga digulingkan oleh militer pada tahun 1968. Ayunan gelombang balik kedua di seluruh dunia pada tahun 1962 mencatat sebanyak 13 pemerintahan di dunia merupakan hasil kudeta, sedangkan pada tahun 1975 tercatat 38 pemerintahan juga hasil kudeta yang sama. Menurut hasil perhitungan yang lain, sepertiga dari 32 negara yang merdeka pada tahun 1958 telah berubah menjadi negara yang otoriter menjelang pertengahan dasa warsa 1970-an. Timur Tengah, di era ini antara lain diwarnai dengan Revolusi Rakyat Libya pimpinan Moamar Khaddafi (1969) dan Revolusi Irak pimpinan Saddam Hussein (1971).

Gelombang demokratisasi ketiga adalah proses demokratisasi yang berlangsung sejak tahun 1974 . Bermula dari Revolusi Mawar di Portugal, gelombang demokrasi ini dalam kurun waktu 5 tahun bergerak ke Spanyol melintasi Eropa Selatan. Setelah itu melanda Amerika Latin dan menuju Asia serta kembali lagi ke Eropa menghancurkan sebagian besar rezim Blok Timur menyusul usainya Perang Dingin akhir tahun 1990-an.

Demokratisasi gelombang ketiga dimulai dengan faktor penyebab yang lebih kompleks dibandingkan dua gelombang terdahulu. Empat di antaranya adalah melemahnya legitimasi rejim otoriter, perkembangan di sektor ekonomi, dampak dari proses serupa di kawasan (snowball effect), dan tekanan dari luar. Huntington memberi sebutan gelombang ketiga (third wave) untuk proses demokratisasi yang terjadi mulai pertengahan 1970-an sampai awal 1990-an.

Di kawasan Timur Tengah, gelombang ini antara lain ditandai dengan munculnya Revolusi Republik Revolusioner Islam Iran (1979) pimpinan Ayatollah Ruhollah Khomeini menggulingkan kekuasaan Shah Mohammad Reza Pahlavi. Revolusi adalah hal yang didambakan oleh segenap rakyat Iran pada tahun 1979. Hal ini dilatar belakangi faktor akumulasi ketidakpuasan dan kekecewaan rakyat Iran pada umumnya terhadap kinerja pemerintah / rezim pimpinan Shah Reza Pahlevi yang berkuasa pada kala itu.

Tingkat inflasi yang tinggi, peningkatan infrastuktur yang tidak seimbang antara pusat dan daerah, jurang pemisah antara si kaya dan si miskin yang terlalu lebar, tuntutan kaum terpelajar akan liberalisasi dan kebebasan akan hak-hak sipil dipandang sebagai titik pemicu revolusi tersebut. Meskipun resiko yang akan dihadapi rakyat akibat revolusi cukup tinggi, rakyat Iran tampaknya cukup siap untuk membayar mahal konsekuensinya. Perubahan tatanan secara radikalpun tak dapat dielakkan lagi.

Demonstrasi pertama menentang Shah dimulai dengan aksi sekumpulan mahasiswa Islam pada Januari 1978. Kerajaan Shah mengerahkan tentara untuk membubarkan demonstrasi dan keputusan ini menyebabkan beberapa mahasiswa terbunuh. Kekerasanpun kembali pecah Pada 18 Februari, tepat 40 hari tewasnya para demonstran yang terbunuh. (http://ms.wikipedia.org/wiki/Revolusi_Iran\#Latar_ Belakang_Revolusi).

Terjadi beberapa demonstrasi di seluruh Iran untuk memberi penghormatan kepada korban mahasiswamahasiswa itu dan juga untuk memprotes kekejaman Shah. Akhirnya, bentrokan terjadi di Tabriz dan ratusan pengunjuk rasa terbunuh. Hal yang sama turut 
terjadi pada 29 Maret dan kali ini di seluruh Iran. Kebanyakan bangunan-bangunan pemerintah rezim Shah dirobohkan dan dimusnahkan, dan sekali lagi, ratusan nyawa menjadi korban. Aksi yang tadinya hanya dilakukan oleh beberapa gelintir mahasiswa berubah menjadi gelombang perlawanan masyarakat Iran yang selama ini memendam kekesalan terhadap rezim Pahlevi.

Saat itu Pahlevi sadar bahwa ia sedang menghadapi situasi revolusi, banyak pihak yang ingin dirinya terguling dari kursi kepemimpinan. Menyadari hal ini, iapun meminta bantuan kepada Amerika Serikat untuk menyokongnya. Amerika ketika itu memiliki kepentingan sangat besar di Iran, karena Iran adalah salah satu Negara yang kaya akan sumber minyak, selain itu posisi Iran dipandang sangat strategis mengingat Amerika sedang terlibat perang dingin dengan Uni Soviet. Awalnya Amerika optimis Pahlevi mampu mengatasi masalah ini dan menyatakan hal ini hanya maneuver politik para oposisi. Tetapi dengan semakin besarnya arus ketidakpuasan serta semakin banyaknya masyarakat yang turun ke jalan, Amerika berpendapat bahwa image Pahlevi sudah hancur dan tidak dapat diselamatkan lagi. Pahlevi harus segera turun tahta dan menyiapkan calon pengganti dirinya/ suksesornya untuk meredakan revolusi ini. Tetapi rencana tersebut tak pernah terwujud karena Ayatollah Khomeini mengambil alih kekuasaan untuk memerintah Iran dengan bantuan rakyat (Encarta Premium 2007). Ayatollah Ruhollah Khomeini, sebagai pemimpin revolusi dengan gelar Vilayat al Faqih menyerukan 4 Program Revolusi, yaitu:

1. Menyiapkan Revolusi

2. Gulingkan rezim lalim, Shah Reza Pahlevi

3. Bentuk pemerintahan Republik Revolusioner Islam Iran

4. Mengekspor Revolusi

Revolusi Iran sebenarnya dimulai pada awal tahun 1977, ketika unjuk rasa hak-hak sipil yang dilakukan oleh para penulis dan pengacara mulai menuntut kebebasan yang lebih. Takut mereka akan menggulingkannya, maka elit pemerintah memperkenalkan reformasi dari atas untuk mencegah revolusi dari bawah. Shah yang mengumumkan adanya reformasi, termasuk persidangan majelis (parlemen). Betapapun juga, reformasi ini jauh dari menyelesaikan masalah, justru membuka jalan untuk menggulingkan pemerintahan Shah (Jatmika, 2000: 111-124).

Pada tanggal 8 September 1978 (Jum'at Kelabu) para serdadu melakukan pembantaian atas ribuan demonstran di Teheran. Sebagai jawabannya, para buruh melakukan pemogokan. Pemogokan itu adalah percikan yang menyulut dinamit yang telah terpasang di seluruh pelosok negeri. Pada tanggal 9 Spetember 1978, para pekerja kilang minyak di Teheran mengeluarkan seruan pemogokan untuk mengungkapkan solidaritas terhadap pembantaian yang dilakukan sehari sebelumnya dan menentang diberlakukannya undang-undang negara dalam keadaan bahaya.

Tepat pada keesokan harinya, pemogokan telah menjalar luas seperti api yang tidak bisa dijinakkan ke Shiraz, Tabriz, Abdan dan Isfahan. Para buruh penyulingan minyak melakukan mogok dimana-mana. Tuntutan ekonomi dari kaum buruh dengan cepat dirubah menjadi tuntutan politik: "Turunkan Shah!", "Bubarkan Savak!”, “imperialis Amerika!” Kemudian pekerja minyak Ahwaz mengadakan mogok, diikuti oleh buruh non-minyak di Khuzistan yang bergabung dengan pemogokan pada akhir September.

Shah yang sedang sibuk mengadakan persiapan untuk sebuah pengasingan yang nyaman, telah mengirimkan keluarganya ke luar negeri, dan mentransfer $\$ 1$ milyar ke Amerika (ini adalah tambahan dari $\$ 1$ milyar atau lebih yang disimpan di Bonn, Swiss dan di bagian dunia lainnya).

Setelah terjadinya perpecahan yang terjadi dalam tubuh tentara, Shah kehilangan semua kendali terhadapnya. Dalam kepanikan, setelah ragu pada awalnya, beliau melakukan langkah terakhir untuk tetap memegang kendali kekuasaan, menunjuk Shahpur Bakhtiar dari Front Nasional sebagai perdana menteri. Akan tetapi manuver tersebut gagal dan krisis tersebut menjadi lebih parah. Pada tanggal 16 Januari 1979, negara ini dalam sebuah keadaan pergolakan 
revolusioner. Tidak ada harapan yang tersisa bagi Shah, yang pada akhirnya harus terbang meloloskan diri dengan pesawat terbang ke Mesir.

\section{PEMBERONTAKAN ARAB (DEKADE 2010-AN)}

Memasuki dekade kedua abad ke-21, kawasan Timur Tengah ditandai dengan geliat gerakan rakyat menggugat berbagai kepemimpinan nasional mereka. Peristiwa itu dikenal sebagai Kebangkitan dunia Arab atau Musim Semi Arab (bahasa Inggris: The Arab Spring; bahasa Arab:, Kebangkitan dunia Arab athThawrât al-Arabiyyah secara harafiah Pemberontakan Arab) meski tidak semua pihak yang terlibat dalam protes merupakan bangsa Arab (Moisi, 2011; Korotayev A., 2011: 139-169).

Yang terjadi adalah gelombang revolusi unjuk rasa dan protes yang terjadi di dunia Arab. Para pengunjuk rasa di dunia Arab mendengungkan slogan Ash-sha'b yurid isqat an-nizam (Rakyat ingin menumbangkan rezim ini).Sejak 18 Desember 2010, telah terjadi revolusi di Tunisia dan Mesir; perang saudara di Libya; pemberontakan sipil di Bahrain, Suriah, dan Yaman; protes besar di Aljazair, Irak, Yordania, Maroko, dan Oman, dan protes kecil di Kuwait, Lebanon, Mauritania, Arab Saudi, Sudan, dan Sahara Barat. Kerusuhan di perbatasan Israel bulan Mei 2011 juga terinspirasi oleh kebangkitan dunia Arab ini.

Protes ini menggunakan teknik pemberontakan sipil dalam kampanye yang melibatkan serangan, demonstrasi, pawai, dan pemanfaatan media sosial, seperti Facebook, Twitter, YouTube, dan Skype, untuk mengorganisir, berkomunikasi, dan meningkatkan kesadaran terhadap usaha-usaha penekanan dan penyensoran Internet oleh pemerintah. Banyak unjuk rasa ditanggapi keras oleh pihak berwajib, serta milisi dan pengunjuk rasa pro pemerintah.

Rangkaian ini berawal dari protes pertama yang terjadi di Tunisia tanggal 18 Desember 2010 setelah pembakaran diri Mohamed Bouazizi dalam protes atas korupsi polisi dan jaminan kesehatan. Dengan kesuksesan protes di Tunisia, gelombang kerusuhan menjalar ke Aljazair, Yordania, Mesir, dan Yaman, kemudian ke negara-negara lain, dengan unjuk rasa terbesar dan paling terorganisir terjadi pada "hari kemarahan", biasanya hari Jumat setelah salat Jumat. Protes ini juga mendorong kerusuhan sejenis di luar kawasan Arab

Pada Juli 2011 $1^{\text {lupdatel }}$, unjuk rasa ini telah mengakibatkan penggulingan dua kepala negara, yaitu Presiden Tunisia Zine El Abidine Ben Ali yang kabur ke Arab Saudi tanggal 14 Januari setelah protes revolusi Tunisia, dan di Mesir, Presiden Hosni Mubarak mengundurkan diri pada 11 Februari 2011, setelah 18 hari protes massal dan mengakhiri masa kepemimpinannya selama 30 tahun. Selama periode kerusuhan regional ini, beberapa pemimpin negara mengumumkan keinginannya untuk tidak mencalonkan diri lagi setelah masa jabatannya berakhir. Presiden Sudan Omar al-Bashir mengumumkan ia tidak akan mencalonkan diri lagi pada 2015, begitu pula Perdana Menteri Irak Nouri alMaliki, yang masa jabatannya berakhir tahun 2014, meski unjuk rasa semakin menjadi-jadi menuntut pengunduran dirinya sesegera mungkin.

Protes di Yordania juga mengakibatkan pengunduran diri pemerintah sehingga mantan Perdana Menteri dan Duta Besar Yordania untuk Israel Marouf al-Bakhit ditunjuk sebagai Perdana Menteri oleh Raja Abdullah dan ditugaskan membentuk pemerintahan baru. Pemimpin lain, Presiden Ali Abdullah Saleh dari Yaman, mengumumkan pada 23 April bahwa ia akan mengundurkan diri dalam waktu 30 hari dengan imbalan kekebalan hukum, sebuah persetujuan yang diterima oposisi Yaman secara tidak formal pada 26 April; Saleh kemudian mengingkari persetujuan ini dan semakin memperpanjang pemberontakan di Yaman.

Pemimpin Libya Muammar Khaddafi menolak mengundurkan diri dan mengakibatkan perang saudara antara pihak loyalis dan pemberontak yang berbasis di Benghazi. Klimaks gejolak politik di Libya ditandai dengan tertangkap dan terbunuhnya Muammar Khaddafi pada Dampak protes ini secara geopolitik telah menarik perhatian global, termasuk usulan agar sejumlah pengunjuk rasa dicalonkan untuk menerima Hadiah Perdamaian Nobel 2011. 


\section{KRISIS POLITIK PARA PEMIMPIN ARAB}

Mengapa gejolak politik bisa menjadi begitu laten dan masif di kawasan Arab serta Timur Tengah pada umumnya? Fakta menunjukkan bahwa para penguasa di Timur Tengah pada umumnya memiliki berbagai krisis politik, antara lain krisis otoritas, ekualitas dan kontinuitas. Selain itu, ketaatan rakyat Arab terhadap pemimpin nasionalnya juga sering dihadapkan pada aneka pilihan ganda yaitu ashabiyah, wathanniyah, qaummiyah dan ummah.

\section{KRISIS OTORITAS}

Krisis otoritas adalah keabsahan untuk berkuasa dan memerintah yang diakui oleh rakyat sendiri maupun bangsa lain. Dalam kenyataan, banyak penguasa Timur Tengah yang mengalami pembangkangan dari berbagai kekuatan politik dalam negeri. Hal itu antara lain tercermin pada munculnya gerakan demonstrasi, pembangkangan umum, kudeta, revolusi, separatisme, irredentisme. Misalnya penguasa Sudan menghadapi pemberontakan di Darfur (Sudan Selatan); Turki menghadapi pemberontakan suku Kurdi; pemerintah Siprus menghadapai gerakan separatisme Siprus Utara yang didukung Turki; dan sebagainya. Merebaknya gerakan rakyat pada peristiwa "Arab Springs" dekade 2010-an merupakan penegasan bahwa krisis otoritas merupakan krisis yang banyak dialami oleh para penguasa di Timur Tengah. Krisis politik yang bersumber dari luar negeri, bisa berujud penolakan pengakuan terhadap penguasa yang ada, embargo, campur tangan hingga intervensi (agresi).

\section{KRISIS EKUALITAS}

Krisis ekualitas adalah krisis kekuasaan yang disebabkan oleh adanya kesenjangan dalam hal tingkat perekonomian dan kesempatan berpolitik antar warga negara pada suatu negara. Keadaan itu pada akhirnya bisa memancing munculnya ketidakstabilan politik. Struktur ekonomi berbentuk piramida runcing, dimana pucuk (raja/ presiden dan keluarga sangat runcing). Sedang masa akar rumput miskin sangat lebar. Urutannya,antara lain sbb:

1. Golongan Sangat Kaya: Raja/ Presiden dan

\section{keluarganya}

2. Golongan Kaya: Elit politik, milter dan bisnis

3. Miskin : Pegawai negeri atau swasta, petani

4. Sangat Miskin: buruh; warga negara kelas dua. (Misal warga Syiah di Saudi bagian Timur; suku Kurdi di Iraq-Iran-Suriah-Turki; warga Palestina di Tanah Pendudukan)

Orang kaya dari Timur Tengah kebanyakan berasal dari keluarga kerajaan. Hal ini tidak terlepas dari sistem politik monarki absolut yang dianut oleh negara-negara Teluk yang memungkinkan keluarga kerajaan mendapatkan kekuasaan ekonomi maupun politik. Dalam daftar 50 orang kaya Arab tahun 2007 yang dikeluarkan oleh Arabia Business, 7 dari 10 orang terkaya di Timur Tengah tersebut berasal dari Saudi. Yang terkaya adalah Pangeran Al Walid Bin Talal AlSaud, keponakan Raja Abdullah. Keluarga Hariri dari Libanon yang menduduki peringkat ketiga juga terhitung memiliki darah Saudi. Kelompok kian kaya, dalam kenyataannya cenderung kian pro-status quo. Misalnya keluarga Saud di Saudi; Al Sabah di Kuwait; Golongan Yunani di Siprus,dll. Sebaliknya kelompok kian miskin kian revolusioner. Misalnya, kaum Hamas di Palestina; Syiah di Saudi- Libanon-; golongan Turki di Siprus Utara; kaum Kurdi di Iraq-IranSuriah-Turki; dll).

Kesenjangan ekonomi dan politik merupakan faktor utama yang menyulut revolusi rakyat Tunisia 2011 yang menggulingkan Presiden Zine al-Abidine Ben Ali. Ia berkuasa sejak tahun 1987 dengan menggulingkan Habib Bourguiba, Presiden Tunisia pertama, yang terpilih lewat pemilu sejak merdeka dari Perancis. Awalnya kepemimpinan Ben Ali, berdasarkan penilaian Dana Moneter Internasional (IMF), Tunisia memiliki catatan bagus dalam pengelolaan keuangan, dan dipuji karena memiliki fondasi ekonomi yang solid dan tetap berupaya melakukan modernisasi.

Rata-rata penguasa yang diktator yang korup dan despotis hanyalah mengandalkan kekuatan militer, polisi dan aparat intelijen untuk menjaga dan melindunginya. Umumnya, para diktator yang berkuasa, selalu menciptakan sistem oligarki, yang terdiri sejumlah elite sipil dan militer yang berkuasa, 
dan menjadi pilar kekuaasaannya. Maka pemerintahan Ben Ali ini, hanya dikendalikan sejumlah elite politik yang berada di sekeliling kekuasaannya. Selanjutnya, Ben Ali membentuk kroni-kroni yang menguasai ekonomi dan industri Tunisia, yang terdiri dari sanak familinya, yang menguasai aset dan sumber alam Tunisia. Mereka terus "membangun" Tunisia, dan menjadi orang-orang yang sangat kaya, di tengah-tengah kemelaratan rakyatnya yang masif.

Mirip seperti Imelda Marcos, Istri Mantan Presiden dari Filipina yang kaya berkat memanfaatkan kekuasaan suaminya; istri Ben Ali Leila Trebelsi, diberitakan telah mengumpulkan 1,5 ton emas dari bank sentral sebelum melarikan diri dari negara itu. Laporan media banyak menyebutkan bahwa sebenarnya yang berkuasa di Tunisia adalah Leila Trebelsi, bukan Ben Ali yang menjabat sebagai presiden. Leila memiliki pengaruh yang kuat dalam pengelolaan urusan pemerintahan di Tunisia, dan anggota keluarganya, telah membuat sebuah dinasti korup serta memainkan peran yang kuat selama 23 tahun Ben Ali berkuasa. Imad Trabelsi, adik dari Leila Trabelsi, digambarkan sebagai simbol terbesar dari korupsi di Tunisia.

Gambaran mengenai betapa akutnya krisis ekualitas di Mesir, antara lain tercermin pada meledaknya demonstrasi selama 18 hari yang akhirnya Presiden Mubarak mundur pada tanggal 11 Februari 2011."Revolusi ini adalah gerakan massa akar rumput yang digerakkan oleh kemelaratan, upah rendah, dan pengangguran," kata Firas Al-Atraqchi, profesor jurnalisme pada Universitas Amerika di Kairo seperti dikutip Al-Jazeera. Tak heran, gerakan ini diikuti oleh hampir semua kalangan yang bahkan tak mengenal demonstrasi sebelumnya. Mereka ini menemukan cara untuk bersuara guna menunjukkan kemarahan mereka (Peterson, 2011).

\section{KRISIS KONTINUITAS}

Krisis kontinuitas adalah keadaan dimana para penguasa di Timur Tengah rawan kelestariannya dari ancaman digulingkan dengan cara-cara yang tidak demokratis. Baik dari ancaman revolusi atau pemberontakan dalam negeri maupun intervensi asing. Intervensi asing ini, dari segi pelakunya, bisa berlangsung antar sesama negara Timur Tengah (intraregional) dan oleh negara di luar regional (ekstraregional). Di lihat dari penyebab atau motif pelaku, intervensi asing, bisa berlangung karena diundang oleh penguasa; diundang oleh oposisi; dan sebagai tamu tak diudang karena mereka memiliki agenda tersendiri.

a) Intervensi Intra-Regional, misalnya tercermin pada keterlibatan Saudi Arabia pada berbagai proses politik di Yaman, merupakan gambaran keterlibatan aktor intra-regional dalam proses politik sesama antar negara Arab. Hal serupa juga terjadi pada keterlibatan Suriah dan Israel dalam berbagai proses politik di Libanon; maupun keterlibatan Turki di Siprus. Contoh lain adalah pecahnya Perang Teluk II yang terjadi pada tahun 1990. Perang dimulai dengan penyerangan dan pendudukan oleh Irak terhadap Kuwait, yang kemudian berujung terhadap ikut campurnya Amerika Serikat dalam perang tadi. Perang ini memuncak pada Februari 1991. Sebenarnya, Irak dan Kuwait semula merupakan partner. Bahkan, Kuwait membantu Irak melawan Iran pada Perang Teluk I tahun 1980-1988 melalui pinjaman-pinjaman dan dukungan diplomatik. Namun, karena adanya tuduhan dari Irak yang menganggap bahwa Kuwait melakukan eksplorasi di wilayah Irak, dan tidak membagi keuntungan dari hasil minyak tadi. Juga adanya tuduhan bahwa Kuwait menghasilkan lebih banyak minyak dibandingkan yang diizinkan oleh Organization Petroleum Exporting Countries (OPEC), yang berakibat pada menurunnya harga minyak ekspor Irak. Sehingga, Irak melakukan penyerangan dan pendudukan atas Kuwait pada tahun 1990.

b) Intervensi Ekstra Regional (Amerika Serikat Ke Berbagai Negara Timur Tengah). Kehadiran pangkalan militer Amerika Serikat di kota Dahran di bagian timur Saudi Arabia merupakan keterlibatan aktor extra-regional yang hadir karena diundang oleh penguasa Saudi Arabia. Keterlibatan berbagai kekuatan asing asal Barat dalam proses kejatuhan Moammar Khaddafi (2010-2011) merupakan cermin keterlibatan extra-regional karena diundang oleh oposisi (NTC). 
Agresi Amerika Serikat ke Afghanistan pasca Peristiwa WTC 2006, merupakan contoh keterlibatan aktor ekstra-regional tanpa diundang siapapun namun lebih didasari motif kepentingan nasional Amerika Serikat.

\section{KRISIS KESETIAAN RAKYAT}

Krisis kepemimpinan beberapa negara Arab dan Timur Tengah pada umumnya, juga dipengaruhi oleh dilema kesetiaan rakyat Arab terhadap pemimpin nasionalnya. Rakyat sering dihadapkan pada aneka pilihan ganda yaitu ashabiyah, wathanniyah, qaummiyah dan ummah (Hudson, 1977).

Pertama, Ashabiyah adalah faham untuk lebih mengutamakan kesetiaan terhadap keluarga tertentu atau faham tertentu, ideologinya, partainya, kelompoknya dan lain sebagainya sehingga merasa paling baik, paling kuat, paling terhormat, dan aneka keutamaan lainnya yang tidak dimiliki kelompok lain. Hal itu antara lain tercermin pada fanatisme sebagian rakyat terhadap beberapa keluarga yang memiliki peran politik kuat di Timur Tengah. Mereka itu antara lain Bani Saud (Saudi Arbia), Bani Hasyim (Hasyimiyah Yordania), al Sabah (Kuwait), dan sebagainya.

Sumber krisis kesetiaan berbasis ashabiyah juga terjadi pada beberapa kelompok masyarakat berdasarkan kesetiaan aliran keagamaan. Misalnya, para anggota kelompok Syi'ah yang tergabung pada gerakan Hizbullah di Lebanon, dalam banyak kasus lebih berorientasi politik ke Iran dari pada kepada pemerintahan pusat di Lebanon. Hal serupa juga terjadi pada kelompok al-Hauthi di wilayah Jebel alDukhan, Yaman Utara, dalam banyak kasus lebih berorientasi politik ke Iran dari pada kepada pemerintahan pusat di Yaman.

Kedua, Qaummiyah adalah semangat untuk lebih mengutamakan kesetiaan terhadap suku tertentu. Misalnya, kesetiaan dan kebanggaan sebagai bangsa Arab yang oleh Hasan al Banna disebut sebagai 'Urubah (Arabisme). Salah satu contoh kongkrit dari semangat qaummiyah adalah upaya pembentukan Uni Republik Arab Mesir dengan Suriah (1958 - 1961) dan berdirinya organisasi Liga Arab pada tanggal 22
Maret 1945. Liga Arab atau Liga Negara-Negara Arab adalah sebuah organisasi yang terdiri dari negara-negara Arab (bandingkan dengan dunia Arab).

Pada tahun 1943, Mesir memprakarsai gerakan Liga Arab. Tujuan Liga Arab ini untuk mempererat persahabatan Bangsa Arab, memerdekakan negara di kawasan Arab yang masih terjajah, mencegah berdirinya negara Yahudi di daerah Palestina. Organisasi ini didirikan pada oleh tujuh negara. Piagamnya menyatakan bahwa Liga Arab bertugas mengkoordinasikan kegiatan ekonomi, termasuk hubungan niaga; komunikasi; kegiatan kebudayaan; kewarganegaraan, paspor, dan visa; kegiatan sosial; dan kegiatan kesehatan. Piagam Liga Arab juga melarang para anggota untuk menggunakan kekerasan terhadap satu sama lain.

Ketiga, Wathaniyah adalah semangat untuk lebih mengedepankan kesetiaan terhadap Negara bangsa (nation-state) dibanding kesetiaan yang lainnya. Misalnya, Irak yang berlatar belakang kesukuan Arab melakukan intervensi terhadap Kuwait yang juga bangsa Arab pada tahun 1990, yang kemudian memicu pecahnya Perang Teluk II. Hal serupa juga terjadi pada tahun 1958 saat Presiden Arab Mesir Gamal Abdel Nasser mengirim pasukan Mesir ke wilayah yang disengketakan dengan negara Arab Sudan.

Contoh lain yang menggambarkan kesetiaan terhadap negara bangsa (wathaniyah) mengalahkan kesetiaan terhadap sesama bangsa Arab (qaummiyah) adalah kegagalan keberlangsungan Republik Uni Arab, atau United Arab Republic (UAR). Uni ini adalah suatu negara yang terdiri atas perserikatan Republik Mesir dan Suriah, pada. UAR didirikan pada 1 Februari 1958. Pendirian tersebut dilandasi kekhawatiran kelompok pimpinan politik dan militer di Suriah akan bahaya komunis yang mengintai. Mereka lalu meminta bantuan dari Gamal Abdal Nasser, pemimpin Mesir.

Perserikatan yang dilakukan mengikat kedua bangsa tersebut ke dalam satu negara, dengan Kairo sebagai ibu kotanya dan Nasser sebagai pemegang tampuk pimpinan. Militer Mesir kemudian dikerahkan masuk ke Suriah, dan berhasil mematahkan ancaman 
komunis.

Lama kelamaan, rakyat Suriah mulai merasa terganggu dengan kondisi penyatuan tersebut. Pemimpin Suriah yang dipaksa untuk menetap di Kairo pun merasa terputus dari pusat kekuatan di Suriah. Selain itu, timbul arogansi dari orang-orang Mesir yang tinggal di Suriah, berlaku seolah-olah Suriah merupakan koloni Mesir. UAR akhirnya bubar pada 1961, setelah terjadi kudeta di Suriah. Namun, Mesir tetap melanjutkan pemakaian nama UAR hingga kematian Nasser pada 1971.

Keempat, Ummah atau 'Alamiyah (Internasionalisme), adalah semangat yang mengedepankan kesetiaan terhadap agama tertentu tanpa membedakan asal muasal keluarga, kesukuan dan negara bangsa. Misalnya, adalah solidaritas berbagai bangsa Islam yang berbeda latar aliran, suku dan negara- bangsa terhadap perjuangan kemerdekaan bangsa Palestina. Bangsa Iran yang bersuku Persia dan berfaham Syiah mendukung perjuangan bangsa Palestina yang bersuku Arab dan berfaham Suni; melalui pertemuan di Teheran pada bulan Februari 2010. Saat itu Pemimpin Besar Revolusi Islam Ayatollah al-Udzma Sayyid Ali Khamenei menerima sejumlah pemimpin perjuangan Palestina yang kini berada di Tehran untuk menghadiri konferensi 'Solidaritas Nasional dan Islam untuk Masa Depan Palestina'. Mereka menekankan bahwa Palestina dan alQuds akan kembali ke pangkuan umat Islam lewat perjuangan, jihad dan resistensi, dan nasib rezim penjajah Israel akan berakhir dengan kekalahan dan kehancuran (Browers, 2009).

\section{CARILAH ILMU WALAU SAMPAI NEGERI ARAB}

Mengapa kita perlu belajar sejarah? Paling tidak ada 3 (tiga) fungsi sejarah. Pertama, mengetahui kapan dan di mana peristiwa penting berlangsung, siapa pelakunya, mengapa bisa terjadi dan apa akibatnya. Kedua, kita bisa mengambil pelajaran yang baik, sekaligus membuang yang buruk. Ketiga, sejarah adalah teori. Maksudnya, jika di kemudian hari kita mengemui peristiwa yang sama ataupun serupa; kita dapat menggunakan sejarah yang serupa, untuk memecahkan persoalan tersebut. Lantas, apa saja pelajaran yang bisa kita petik dari berbagai krisis kepemimpinan Arab ini?

\section{Never Ending Leadership and National Character Building.}

Keberadaan berbagai krisis kepemimpinan( krisis otoritas, ekualitas, kontinuitas) dan berbagai krisis kesetiaan (ashabiyah, wathaniyah, qaummiyah, ummah) yang menimpa berbagai bangsa Arab bisa jadi adalah hikmah utama yang bisa dipetik oleh bangsa manapun tatkala mengkaji betapa rumitnya problem yang dialami oleh beberapa bangsa Arab dalam membentuk dan menjaga persatuan bangsa dan negaranya. Berbagai paparan di atas menggambarkan bahwa proses pembentukan, pemeliharaan dan pelestarian pembangunan nilai-nilai bangsa (national character building) adalah proses yang tidak pernah selesai (Phares, 2010).

\section{Pentingnya Sistem Yang Holistik- Elastis-Adaptif.}

Revolusi Yasmin berupa gerakan perlawanan rakyat di Tunisia berhasil secara dramatis menjatuhkan Presiden Zine al-Abidine Ben Ali dan bahkan membuat dia melarikan diri ke Arab Saudi mempunyai resonansi politik yang besar terhadap Dunia Arab. Revolusi rakyat Tunisia itu telah membawa efek karambol terhadap negara-negara Arab. Apa yang terjadi di Tunisia, telah menginspirasi beberapa negara di Timar Tengah untuk melakukan protes dan penggulingan terhadap rezim yang telah lama berkuasa. Di Sudan, juga telah melakukan referéndum untuk pemisahan Sudan Selatan. Di Mesir, rakyat mengikuti langkah Tunisia, terjadi demo besar yang akhirnya menggulingkan Presiden Hosni Mubarak. Di Libya gerakan rakyat dibawah NTC berhasil menggulingkan Moammar Khadaffi. Sementara Yaman dan Suriah juga terjadi demonstrasi sebagai bentuk "deman Tunisia."

Fakta tersebut menegaskan pentingnya kesadaran bahwa sistem politik adalah bersifat holistik, dimana sebuah gejala yang berlangsung pada suatu tempat bisa memengaruhi anggota sistem yang lainnya. Sebuah sistem politik juga harus bersifat adaptif (cepat 
tanggap dan mampu segera menyesuaikan dengan dinamika perubahan di lingkungan internal maupun ekternalnya). Keterlambatan beradaptasi, bisa menyebabkan kegagalan dan kemacetan sebuah sistem politik. Kerusakan bisa berupa demonstrasi, pemogokan, amuk masa, kudeta hingga revolusi rakyat (Goldstone; John T., Hazel, Jr., 2011).

\section{Pemimpin, Rakyat Dan Martabat Bangsa}

Muammar Khaddafi, seorang pemimpin yang masyhur selama 42 tahun, akhirnya mati dengan cara tragis. Tertangkap di gorong-gorong; setelah memohon keselamatan akhirnya ditembak jarak dekat; jenazah dipajang selama tujuh hari dipajang di kulkas sebuah super market; setelah mulai membusuk akhirnya jenazah dimakamkan di sebuah padang pasir yang dirahasiakan (Posusney and Angrist, 2005). Seperti itukah cara yang bermartabat dalam memperlakukan (bekas) seorang pemimpin bangsa? Bukankan martabat sebuah bangsa antara lain dapat diukur dari bagaimana anak bangsa tersebut memperlakukan (bekas) pemimpinnya? Lantas apa pelajaran yang bisa kita petik?

\section{KESIMPULAN}

"Raja adil raja disembah. Raja lalim, raja disanggah" barangkali merupakan ungkapan yang tepat untuk menggambarkan bagaimana korelasi sebuah kepemimpinan dengan cara anak bangsa memperlakukan (bekas) pemimpin bangsanya. Kalau kita meyakini adagium bahwa "Tolok ukur martabat suatu bangsa antara lain dilihat dari cara rakyat memperlakukan (bekas) pemimpinnya", maka pemimpin, hendaklah hadir dengan cara terhormat. Berakhir dengan cara menghormat. Rakyat juga harus belajar menghormati pemimpin dengan cara terhormat. Namun, prinsip resiprositas adalah hukum alam; ibarat "siapa menanam, siapa mengetam". Supaya pemimpin nantinya diperlakukan secara bermartabat oleh rakyatnya, terlebih dahulu, ia semasa berkuasa hendaknya memperlakukan rakyatnya dengan cara yang bermartabat pula.

\section{CATATAN AKHIR}

Saat tulisan disusun, krisis politik dan kepemimpinan nasional tengah terjadi pada Presiden Yaman Ali Abdullah Saleh dan Presiden Suriah Bashar al Assad. Di Yaman Tanggal 4 Juni, Presiden Ali Abdullah Saleh terluka dalam serangan terhadap masjid di tempat perlindungannya di ibu kota Yaman, Sana'a, menyebabkan ia dan 35 anggota keluarganya, termasuk istrinya, serta Perdana Menteri dan Juru Bicara Parlemen Yaman, meninggalkan Yaman ke Arab Saudi. Di Suriah, bentrokan dan kekerasan terus berlangsung antara pasukan pemerintah dan aktivis oposisi. Setidaknya lebih dari 2.200 orang tewas akibat kekerasan.

\section{REFERENSI}

Browers, Michaelle. 2009. Political Ideology in the Arab World: Accommodation and Transformation. New York: Cambridge University Press.

Encarta Premium. 2007. Iran/History/H. Growing Opposition To The Shah

George, Lenczowski. 1993. The Middle East In World Affairs. USA: University of Californa at Berkeley.

Goldstone, Jack A., Hazel, John T., Jr. 2011. Understanding the Revolutions of 2011: Weakness and Resilience in Middle Eastern Autocracies. Foreign Affairs, 14 April.

Hudson, Michael C. 1977. Arab Politics The Search To Legitimacy. Yale University

Huntington, Samuel P. 1993. Gelombang Demokratisasi Ketiga. Jakarta: PT. Grafity Press.

Jatmika, Sidik. 2000. Amerika Penghambat Demokrasi. Yogyakarta: Penerbit BIGRAF.

Jatmika, Sidik. 2011. Timur Tengah: Never Ending Conflict? Diktat Mata Kuliah Politik Pemerintahan Timur Tengah, proses terbit.

Korotayev A., Zinkina J. 2011. Egyptian Revolution: A Demographic Structural Analysis. Entelequia. Revista Interdisciplinar, 13: 139-169

Markoff, John. 2002. Gelombang Demokrasi Dunia, Gerakan Dan Perubahan Politik. Yogyakarta: Pustaka Pelajar.

Moisi, Dominique. 2011. An Arab Spring? Project Syndicate, 26 Januari.

Ochsenwald, William \& Sidney Nettleton Fisher. 1979. Impact of World War I Upon The Middle East. Dalam The Middle East, A History. New York: McGraw-Hill Comp.

Peterson, Scott. 2011. Egypt's revolution redefines what's possible in the Arab world. 11 Februari 2011. Diakses pada 12 Juni 2011.

Phares, Walid. 2010. Coming Revolution: Struggle for Freedom in the Middle East. New York: Simon \& Schuster.

Posusney, Marsha Pripstein; Angrist, Michele Penner (ed). 2005. Authoritarianism in the Middle East: Regimes and Resistance. Boulder: Lynne Rienner.

Ramadhanny, Fitraya. 20 Oktober, 2011. Dor! Khadafi Tewas Tertembak di Kepala. detikNews. 